\title{
O INSTITUTO DE COIMBRA E A UNIVERSIDADE
}

\author{
LICÍNIA RODRIGUES FERREIRA \\ Projecto Instituto de Coimbra \\ Biblioteca Geral da Universidade de Coimbra
}

A Biblioteca Geral da Universidade de Coimbra desenvolve, desde 2008, um projecto de recuperação da memória do Instituto de Coimbra. Tendo-se extinguido gradualmente no final do século passado, esta academia científica e literária foi, no entanto, desde 1852, um organismo influente na evolução da Universidade, trabalhando a par desta para o progresso dos conhecimentos. A disposição do artigo $17^{\circ}$ dos seus últimos estatutos publicados, em 1967, previa que o património da academia, em caso de dissolução, fosse integrado no património da Universidade de Coimbra (UC). Por esse motivo, o fundo documental do Instituto de Coimbra foi, em 2006, incorporado nas colecções da Biblioteca Geral. Com o apoio da Fundação para a Ciência e a Tecnologia (FCT), que financia duas bolsas de gestão de ciência e tecnologia e uma bolsa de investigação, o Projecto Instituto de Coimbra tem por missão realizar o tratamento da documentação e traçar a história da academia.

Um dos seus principais legados é a revista $O$ Instituto, à qual o Projecto reconheceu a devida importância e a necessidade de a tornar facilmente acessível, procedendo à digitalização da totalidade dos 141 volumes e dotando-a, além disso, de um sistema de pesquisa em texto integral. Esta edição digital encontra-se disponível na página da internet da Biblioteca Geral (http://www.uc.pt/bguc/BibliotecaGeral/ InstitutoCoimbra/Projecto/). Os cerca de quatro mil títulos de artigos que a revista integra serão também recuperáveis a partir do catálogo das Bibliotecas da UC.

O espólio compõe-se do que ficou preservado do Arquivo do Instituto, nomeadamente, actas de sessões da Assembleia Geral, das Classes e da Direcção, correspondência, contabilidade, formulários e outros documentos de ordem diversa. Quanto ao património bibliográfico, a sua nota distintiva é o elevado número de títulos de periódicos, nacionais e estrangeiros, obtidos em grande parte pela permuta com a revista $O$ Instituto. Porém, a componente monográfica é igualmente de extrema importância, facto que os membros do Projecto Instituto de Coimbra têm vindo a comprovar pela introdução de uma relevante percentagem de registos novos na base comum das bibliotecas da Universidade e pela procura crescente por parte dos leitores. Por outras palavras, a colecção do Instituto de Coimbra revela-se única, pelas condições 
específicas da sua construção, inerentes ao funcionamento de uma academia, e essa especificidade tem-se manifestado cara aos utilizadores das bibliotecas da Universidade.

A integração do património do Instituto na Universidade de Coimbra é já bem significativa da relação estreita que um e outra mantiveram. Nasceu no seio de uma associação de teatro universitário, a Academia Dramática, em resultado de uma cisão interna, pela qual um grupo de sócios decidiu juntar-se em agremiação independente. Adoptaram então uma orientação mais alargada, acrescentando à vocação artística e literária um pendor fortemente científico, que, com efeito, responderia melhor às preocupações destes estudiosos. Desde logo se aliaram à Universidade em termos de instalações, pois se mantiveram sediados em edifícios afectos à cidade universitária (Colégios de São Paulo Apóstolo e Eremita, Arco do Bispo, Colégio de São Bento e Rua da Ilha). Em matéria de financiamento, porém, dispunham de meios próprios, provenientes, na sua maior parte, das quotas dos sócios e das assinaturas da revista $O$ Instituto, para além de subsídios do Estado.

As figuras de maior destaque do meio universitário constituíam a componente principal de sócios do Instituto, os efectivos, na medida em que assumiam um papel mais activo nos trabalhos da corporação. Os órgãos directivos e a presidência do Instituto foram ocupados por nomes respeitados da Universidade (e alguns mesmo na cena política nacional), que em certos casos chegaram a pertencer aos seus cargos superiores (Filomeno da Câmara Melo Cabral, António Augusto da Costa Simões, Bernardino Machado, Júlio Augusto Henriques, Francisco Miranda da Costa Lobo, etc.).

A dimensão científica desta ligação entre a Universidade e o Instituto de Coimbra, com tudo o que nela está envolvido, ergue-se como o produto mais perene desta cooperação. Neste aspecto, dois veículos principais testemunharam a estreita união: a revista $O$ Instituto e os encontros científicos. Ao longo dos 130 anos de publicação (1852-1981), O Instituto foi lugar privilegiado de divulgação da produção científica da Universidade de Coimbra - para além de trabalhos por sócios nacionais e estrangeiros, pertencentes a outras instituições. Esse fenómeno foi particularmente relevante nos primeiros 50 anos da revista, que coincidiram com uma época em que a Universidade dispunha de escassas publicações desta natureza. Assim, encontramos n' $O$ Instituto artigos resultantes de investigações realizadas por docentes universitários, em muitas áreas, relatórios de visitas desses docentes a estabelecimentos no exterior, e textos referentes às relações da Universidade com outros estabelecimentos de ensino. 
Durante alguns anos, $O$ Instituto publicou também dados estatísticos e programas de cadeiras das diferentes Faculdades, bem como outras notícias relativas ao governo da Universidade, sendo ainda portadora esta revista de testemunhos das propostas de reforma dos estudos apresentadas no período anterior à República.

No que se refere a encontros científicos, verificamos uma constante colaboração da Universidade de Coimbra na realização de conferências e de comemorações promovidas pelo Instituto. Partindo quer da Universidade quer do Instituto o convite aos conferencistas, as duas entidades associavam-se para receber personalidades nacionais e estrangeiras, beneficiando ambas da colaboração. O Instituto conseguiu deste modo juntar alguns nomes importantes à sua lista de sócios, que enviavam à sociedade as suas obras, e, por outro lado, em conjunção com a Universidade pôde mais facilmente estabelecer um intenso intercâmbio com outras sociedades científicas e literárias.

A dimensão relacional do Instituto, com a Universidade e com outros organismos, será decerto contemplada num estudo maior que o Projecto pretende avançar, na sua componente de investigação da história desta academia. No final, poderse-á compreender melhor a importância do Instituto de Coimbra em particular, e das academias em geral, na evolução da ciência em Portugal. De certa forma, este Projecto vem assim reunir-se a outros projectos de História da Ciência que a Universidade está a promover. Julgamos que a Biblioteca Geral e o Projecto Instituto de Coimbra dão, assim, continuidade aos esforços do Instituto, divulgando à comunidade universitária e colocando à sua disposição uma herança fecunda construída ao longo de 150 anos de actividade. 